\title{
THE ROLE OF PSYCHOLINGUISTICS IN LANGUAGE LEARNING AND TEACHING
}

\author{
Norita Purba \\ Applied Linguistics, Graduate School, Yogyakarta State University, norita.purba2016@student.uny.ac.id
}

\begin{abstract}
Psycholinguistics has provided numerous theories that explain how a person acquires a language, produces and perceives both spoken and written language. The theories have been used in the field of language teaching. Some experts use them as the basic theories in developing language teaching methods. It is known as psycholinguistics approach. Psycholinguistic approach views learning as a cognitive individual process happening within the individual and then moves to the social dimension. As an approach, there are some methods which were developed based on psycholinguistics theories such as natural method, total physical response method, and suggestopedia method. These methods apply psycholinguistic principles that how a person acquires his/her mother tongue or first language (First Language Acquisition), learns his/her second or third language (Second Language Learning), perceives a language (Language Perception), and produces language (Language Production). Language perception refers to listening and reading, while the language production refers to speaking and writing. Listening, reading, speaking and writing are called as the four of language skills. Specifically, psycholinguistics helps to understand the difficulties of these four skills both intrinsic difficulties and extrinsic difficulties. Psycholinguistics also helps to explain the errors students do in the language learning. Moreover psycholinguistics also defines some kinds of brain disorders that affect language learning performance such as agraphia and aphasia which must be treated properly. Psycholinguistics mainly helps teachers to consider the use of appropriate method to teach that four language skill.
\end{abstract}

Keywords: psycholinguistics, approach, method, teaching

Psycholinguistics is an integration of two disciplines; psychology and linguistics. Psychology is the study of mind and behavior; linguistics is the study of language. So, in general, psycholinguistics can be defined as the study of mind and language. It is concerned with the relationship between the human mind and the language as it examines the processes that occur in brain while producing and perceiving language.

Psycholinguistics covers three main points; language production, language perception and language acquisition. Language production refers to the processes involved in creating and expressing meaning through language. Language perception refers to processes involved in interpreting and understanding both written and spoken language. Language acquisition refers to processes of acquiring a native or a second language.

Psycholinguistics has provided numerous theories that explain the three points above. The theories have been very useful in the field of language teaching. Some experts use them as the basic theories in developing language teaching methods. It is known as psycholinguistics approach. Psycholinguistic approach views that language and thought as related but completely independent phenomena. Learning is viewed as a cognitive individual process happening within the individual and then moves to the social dimension.

Psycholinguistics as a study of the psychology of language is realized in language teaching. It helps to study the psychological factors that are possibly involved in languages learning. Psycholinguistics focuses on the application of the actual language and communication. It is necessary to make a decision in applying various methods that allow students to easily understand a language.

As an approach, there are some methods which were developed based on psycholinguistics theories and the methods have been used widely in the field of language teaching over the countries. Some kinds of the method will be explained in this paper. To avoid misconception, some terms related to psycholinguistics and language learning and teaching will also explain in this paper.

\section{Review of Literature}

Psycholinguistics is simply defined as the study of the relationship between human language and human mind (Maftoon and Shakouri, 2012). In short, three important processes are investigated in psycholinguistics: (1) language production, (2) language comprehension, and (3) language acquisition. 
From many questions that psycholinguistics attempts to answer, it, specifically, addresses two questions (1) what knowledge of language is needed for us to use language? and (2) what cognitive processes are involved in the ordinary use of language?

Psycholinguistics has developed rapidly and expanded into several sub-disciplines as cited in Chaer (2015) below:

1. Theoretical psycholinguistics. It focused on theories of language relating to human mental processes in language, such as phonetics, diction, syntax design, discourse, and intonation.

2. Developmental psycholinguistics. It is related to language acquisition, both first language acquisition (L1) and second language acquisition (L2). It examines phonological, semantic, and syntactic acquisition, process in stages, gradually, and integrated.

3. Social psycholinguistics related to the social aspects of language, including social identity.

4. Educational psycholinguistics discussed general aspects of formal education at school, including the role of language in teaching reading teaching proficiency, and improving language ability to express thoughts and feelings.

5. Neuro-psycholinguistics focused on the relationship between language, language production, and the human brain. Neurology experts have managed to analyze the biological structure of the brain and analyzed what happens with the input language and how language output programmed and set up in the brain.

6. Experimental psycholinguistics covered and experimented in all language productions and language activities, language behavior, and language outcome.

7. Applied psycholinguistics concerned with the application of the findings of six sub-disciplines of psycholinguistics explained before in certain areas that require it, including psychology, linguistics, language learning, neurology, psychiatry, communications, and literature.

Psycholinguistic approach views language and thought as related but completely independent phenomena (Claros, 2009). In the psycholinguistic approach, the individual internal cognitive processes are activated so that activation allows the individual to access the comprehensible input needed to further advance in the acquisition of the L2 (Long, 1996 cited in Claros, 2009). Krashen (1985) argues that to understand and learn language, s/he must be exposed to the linguistic input that is a little beyond his/her current level of competence. Krashen explains his view in his famous $i+1$ concept which indicates that the input the learner receives must contain some slight amount of new information in addition to what s/he already knows. To Krashen, a comprehensible input is not just a necessary condition, but it is the sufficient condition.

In relation to language teaching, developmental psycholinguistics and applied psycholinguistics play significant roles in formulating effective ways of teaching. Psycholinguistics theory covered the language development of humans, in accordance with humans' physical and mental development. These theories are considered in designing language teaching programs and materials in order to be effective for the second language learners master the target language.

Harras and Andika (2009) mention three kinds of language teaching methods which are developed according to psycholinguistics principles: natural method, total physical response method, and suggestopedia method.

\section{Language Learning and Language Acquisition}

Field (2004) states that the term is used for infants acquiring their native language (first language acquisition) and for those learning a second or foreign language (second language acquisition). The use of the terms is still unproblematic. Some experts use the term 'language learning' and some use the term 'language acquisition'. Chaer (2015) explains that term 'language learning' is used because some experts believe that second language can be master by learning the language intentionally and consciously. This is different from the first language and mother tongue which is acquired naturally and unconsciously without a formal setting. The term of language acquisition is used because it is believed that second language or third language is acquired either formally or informally. In this paper, which is used is a term that refers to the language learning second language acquisition.

There are two types of language learning; naturalistic language learning and formal language learning. Naturalistic language learning is learning a language naturally, consciously, and unintentionally. 
This usually occurs in bilingual or multilingual society. Otherwise, formal language learning takes place in the classroom with teachers, materials and learning aids.

Thus, this paper will use the term 'language learning' which will refer to the processes of a person masters a second language or a foreign language in a formal education setting.

\section{Factors Affecting Language Learning}

Some students learn a new language more quickly and easily than others. This fact related to the crucial factors influencing success that are largely beyond the control of the learner. According to Lightbown and Spada (2006:58-74) mention some factors affecting language learning.

\section{a. Intelligence}

The term 'intelligence' has traditionally been used to refer to performance on certain kinds of tests. These tests are often associated with success in school, and a link between intelligence and second language learning has sometimes been reported.

\section{b. Aptitude}

Specific abilities thought to predict success in language learning have been studied under the title of language learning 'aptitude'. Research has characterized aptitude in terms of the ability to learn quickly. Thus, we may hypothesize that a learner with high aptitude may learn with greater ease and speed but those other learners may also be successful if they persevere.

\section{c. Learning Style}

The term 'learning style' has been used to describe an individual's natural, habitual, and preferred way of absorbing, processing, and retaining new information and skills. Some people say that they cannot learn something until they have seen it. Such learners would fall into the group called 'visual' learners. Other people, who may be called 'aural' learners, seem to learn best 'by ear'. For others, referred to as 'kinesthetic' learners, a physical action such as miming or role-play seems to help the learning process. These are referred to as perceptually-based learning styles.

\section{d. Personality}

A number of personality characteristics have been proposed as likely to affect second language learning. It is often argued that an extroverted person is well suited to language learning. Another aspect of personality that has been studied is inhibition. It has been suggested that inhibition discourages risk-taking, which is necessary for progress in language learning. Furthermore, learner anxiety-feelings of worry, nervousness, and stress that many students experience when learning a second language- has been extensively investigated. Recent research investigating learner anxiety in second language classrooms acknowledges that anxiety is more likely to be dynamic and dependent on particular situations and circumstances. Several other personality characteristics such as self-esteem, empathy, dominance, talkativeness, and responsiveness have also been studied. However, it has been not easy to empirically demonstrate the effect of personality in language learning.

\section{e. Motivation (Intrinsic)}

Motivation has been defined in terms of two factors: learners' communicative needs and their attitudes towards the second language. If learners need to speak the second language in a wide range of social situations or to fulfil professional ambitions, they will perceive the communicative value of the second language and will therefore be motivated to acquire proficiency in it. Likewise, if learners have good attitudes towards the speakers of the language, they will desire more to learn it.

\section{f. Motivation (Extrinsic)}

Teachers also influence on students' behavior and motivation in language learning. Teacher is one of students' reasons for studying the second language or having good attitudes 
toward the language learning. Teachers can give a positive contribution to students' motivation to learn if classrooms are places that students enjoy coming to because the content is interesting and relevant to their age and level of ability, the learning goals are challenging yet manageable and clear, and the atmosphere is supportive.

\section{g. Culture and Status}

There is some evidence that students in situations where their own culture has a lower status than that of the culture in which they are learning the language make slower progress. Social factors at a more general level can affect motivation, attitudes, and language learning success. One such factor is the social dynamic or power relationship between the languages.

\section{h. Age}

Second language learning is influenced by the age of the learner. Children, who already have solid literacy skills in their own language, seem to be in the best position to acquire a new language efficiently. Motivated, older learners can be very successful too, but usually struggle to achieve native-speaker-equivalent pronunciation and intonation. Research found that age distinguishes children and adults in learning second language in certain aspects such as phonology, morphology, and syntax.

\section{Approach and Method}

Harmer (2001) gives distinctive definition of these the three terms. Approach refers to theories about the nature of language and language learning serving as the source of practices and principles in language teaching. An approach describes how language is used and how its constituent parts interlock - in other words it offers a model of language competence. An approach describes how people acquire their knowledge of the language and make statements about the conditions which will promote successful language learning.

A method is the principal realization of an approach. The originators of a method have arrived at decisions about types of activities, roles of teachers and learners, the kinds of material which will be helpful, and some model of syllabus organization. Methods include various procedures and techniques as part of their standard fare.

\section{Psycholinguistics Approach}

No child fails to learn a native tongue and it is mainly learned before the age of five. Children are not taught language formally, but they all reach the same level of proficiency in using their native tongue by the time schools begins. Therefore psycholinguistics approach supports the idea that language acquisition is innately determined and it is rewired by birth since both acquisition and improvement in language are a biological process. Acquiring a language requires perception skills, cognition abilities, and other mechanism that are related with language.

Students are considered as people that always involve the three domains of psychology -cognitive, affective, and psychomotor- in their daily activities. The ability to use both receptive language (listening and reading) and productive (speaking and writing) involving the three domains earlier. The forms of language are organized in the mind of human beings with interdependent connection of memory, perception, thought, meaning, and emotion (Demirezen, 2004).

Psycholinguistic approaches to language learning conceive language learning as a cognitive and individual process in which knowledge is constructed as the learner is (1) exposed to comprehensible input, (2) is given opportunities to both, negotiate, and (3) receive negative feedback. Psycholinguistic approaches to language learning tend to agree that a learner needs to be exposed to input (Carlos, 2008).

One of the most widely studied theories of input is Krashen's input hypothesis (1985). This theory predicts the likelihood for a learner to acquire a language when he/she is exposed to comprehensible input. Thus, to increase the chances for input comprehension, input should be just one step beyond the learner's current stage of linguistic competence.

The interaction hypothesis asserts that besides the input the learner is exposed to, manipulation of such input through interaction is what forms the basis for language development. According to Long (1997) input comprehensibility increases as learners interact and use different type of interactional 
modifications (comprehension checks, confirmation checks, and clarification requests) to overcome communication breakdowns. Long's work sparkled interest among the so-called interactionist who turned their research agendas to examine how speakers modify their speech and interaction patterns to allow their interlocutors to participate, understand, and keep the flow of conversations.

The psycholinguistics approach focuses upon what humans know when they talk and how they acquire that knowledge and how that knowledge is put to use. Matlin (1994) states that the central approach of psycholinguistics theory is how people learn a language biologically and what transformational rules that enable people understand the language. This means that developmentally appropriate instruction must be considered in language learning.

\section{A. Psycholinguistics Approach and Four Language Skills}

Psycholinguistics theories have explained the mental processes that occur in human brain during a person produces and perceives a language. Language perception includes the activity of listening and reading, while the language production includes the activity of speaking and writing. The four activities are called as the four of language skills. Following will be described some benefits of psycholinguistics theories in language learning and teaching as explained by Demirezen (2004).

\section{Psycholinguistics Approach and Listening Skill}

Psycholinguistics researchers have indicated that in teaching listening, the intrinsic and extrinsic difficulties should be overcome in order to reach to a highly qualified listening activity. Intrinsic difficulty refers to the speed of the speech, number of unknown words, and prior knowledge about topic. Extrinsic difficulty refers to students' interest, motivation, purpose of listening activity, and noise in the environment.

Psycholinguistics knowledge will help teacher to reduce the intrinsic and extrinsic difficulties. Teacher can prepare a listening text with topic that is familiar for students, consisting of 100 words, and including 10 new vocabulary items. Teacher also minds about the reading speed and the noise of environment. Moreover, teacher can increase students' interest and motivation by designing an interesting and comfortable class.

\section{Psycholinguistics Approach and Reading Skill}

Psycholinguistics approach resorts to text-based approach as a case of bottom-up processing so as to emphasize the comprehension activity and top-dawn processing to stress the fact that comprehension rests primarily on students' knowledge base.

Bottom-up processing happens when someone tries to understand language by looking at individual meanings or grammatical characteristics of the most basic units of the text and moves from these to trying to understand the whole text. Top-down processing of language happens when someone uses background information to predict the meaning of language they are going to read to. Rather than relying first on the actual words, they develop expectations about what they will read, and confirm or reject these as they read.

This theory emphasizes that the understanding the meaning of a text essentially rests on the prior knowledge of students. Psycholinguistics helps learners to reduce the intrinsic difficulties in reading activity by arousing the interest of the students onto the reading text. Teachers need to provide authentic and contextual reading material because if students are not properly exposed to authentic materials they may fail in seeing their relevance to the real world.

\section{Psycholinguistics Approach and Writing Skill}

Psycholinguistics helps in understanding the students' mistakes in writing. It has a clear contribution on spelling mistakes since in English words are not spelled as they sound. There is a hardship on this case because storing of the spelling of words and retrieve them on demand is very difficult.

Psycholinguistics approach indicates that there are mistakes in writing caused by agraphia, which must be treated properly. Psycholinguistics helps to find interesting topic to write. It serves to decrease the level of the difficulties in writing. It helps to specify the writing levels and writing types. It pins down the mechanic mistakes on punctuation and suggests certain cures for them. 


\section{Psycholinguistics Approach and Speaking Skill}

Psycholinguistic approach has a workable control over the field of teaching speaking as a skill. It has specified several difficulties on speaking such as students' oriented difficulty. Psycholinguistics also explains that personality, like introvert and extrovert students, affects students' performance in language learning. Speaking defects like voice disorders, stuttering, and disarticulation are also psychological in origin caused by personality factor.

There are also some traumatic disorders such as aphasia and autism caused by localized in damage. It is recommend therapies and counseling practices for such difficulties. Thus, the investigations of psycholinguistic approach have provided solutions for almost each type of language learning difficulty.

With the knowledge, teachers can apply the appropriate techniques to teach speaking skills by considering the condition of the learner and find interesting topics to be discussed in speaking class.

\section{Language Teaching Methods of Psycholinguistics Approach}

An approach in language teaching consists of theories of the nature of language and the theories of language learning. Language teaching methods are concretization of language teaching approaches. A method of language teaching can be well understood if its fundamental theories are clearly understood. Fundamental theories in developing language teaching methods are divided into two main theories; the theory of language and the theory of language learning.

There are three fundamental theoretical views in developing the language teaching method: structural theory, functional theory, and interactional theory. Structural theory views language as a system of grammatical unit: phrases, clauses, sentences, affixes, and soon. Functional theory views language from its function as a mean of communication: informational, emotional, persuasive, and social. Interactional theory views language as a mean to realize interpersonal relationship and as a performance of social transaction between individual and society. Each view implicates differently in the development of language teaching method.

Beside the theory of language, the developing of language teaching method is also based on the theory of language learning that related to two main questions; (1) what cognitive process that involved in language learning, and (2) what condition are needed to reach a high quality of language learning activity. Psycholinguistics has clearly answered these two questions. Therefore, psycholinguistics has been used widely as fundamental theory in developing language teaching method. Some methods which were developed based on psycholinguistic approach are described as following (Harras and Andika, 2009)

\section{Natural Method}

This method is developed by Tracy D. Terrel. This method believes that language learning is a reproduction of the way humans naturally acquire their native language. This method rejects earlier methods such as the audiolingual method. Psycholinguistic principles in language learning according this method are as following.

a. Language mastery relies on learning language skills in natural context and less on conscious learning of grammatical rules.

b. Learning a language is an effort to develop communicative competence, the ability to understand the speech of native speakers and native speakers understand the learners' speech without any error which can interfere with meaning.

c. Comprehension is primary than production.

d. The model that underlies this method is five monitors theory: (1) acquisitionlearning hypothesis, (2) natural order hypothesis, (3) monitor hypothesis, (4) feedback hypothesis, (5) affective filter hypothesis.

The consistency of this method is shown by natural technique developed by teacher. Teacher stimulates the learners to competence activity such as problem solving, game, and humanistic affective. Problem solving is designed to train learners to find out a right situational answer or solution. Games are considered as an interlude activity, but it is designed to improve 
students' language competence. Humanistic affective is designed to implicate opinions, feelings, ideas, and reaction to language learning activity.

\section{Total Physical Response Method}

This method is developed by psychologist from San Jose State College, United States, James J. Asher (1966). Psycholinguistic principles in language learning according this method are as following.

a. Language competence will improve significantly by involving kinesthetic sensory system in language learning. This related to the fact that children are given utterances that require them to move physically.

b. Comprehension is primary rather than speech production. Students are directed to achieve comprehension competences before they try to speak or write.

Related to kinesthetic theory, it is believed that there is a positive correlation between physical movements and students' language achievement. It becomes the focus in designing and applying appropriate language teaching technique in a certain topic.

A spacious classroom is required in applying this method. The class ideally consists of 20-25 students. This method can be applied to teach children or adults. Grammatical rules are presented in imperative sentences because basically all materials are presented in imperative sentences. In this method, dictionary is unneeded because the meaning of words will be expressed by physical activities. Students usually do not get homework because language learning is performed together in the classroom.

\section{Suggestopedia}

This method is developed by Georgy Lazanov, a psychiatrist in Bulgaria in 1975. Psycholinguistic principles in language learning according this method are as following.

1. Humans can be directed to do something by giving them a relaxed atmosphere and opened and peaceful mind. These will stimulate nerves to easily respond and store the information for longer.

2. Before the lesson started, students are persuaded to relax their body and mind in order to gather hypermnestic ability, it is an incredible supermemory.

3. The classroom is set up with dim light, comfortable seats, relaxed atmosphere and classical music.

4. Laboratorial program and strict grammar exercise are rejected in the class.

5. Generally, material is presented in a long dialogue. The characteristics of the dialogue are: (a) emphasizes vocabularies and content, (b) related to the real life, (c) practical utility, (d) relevant emotionally, and (e) some words are underlined and given the phonetic transcription.

Each meeting in this method is divided into three time allocations. The first is reviewing the previous topic through discussion, games, sketch, or role playing. If students do some mistakes, teacher corrects it carefully to keep a positive atmosphere. The second is distributing the dialogue traditionally. The third is relaxing students. This is divided into two: active activity and passive activity.

\section{References}

Alduais, A. M. S. (2012). Integration of Language Learning Theories and Aids Used for Language Teaching and Learning. A Psycholinguistic Perspective. Journal of Studies in Education, Vol 2, No. 4.

Chaer, A. (2015). Psikolinguistik: Kajian Teori. Jakarta: PT Rineka Cipta 
Claros, M.S.C. (2008). Psycho-linguistic and socio-cultural approaches to language learning: A never ending debate. Colombian Applied Linguistics Journal, 10(1), 142-154.

Demirezen, M. (2004). Relation between Psycholinguistic Approach and Foreign Language Learning and Teaching. Ondokuz Mayis Universitesi Fakultesi Dergisi, 17, 26-36.

Field, J. (2004). Psikolinguistics. The Key Concept. London: Routledge.

Harmer, J. (2001). The Practice of English Language Teaching. Third Edition. London: Longman.

Harras, K. A., \& Bachari, A. D. (2009). Dasar-dasar Psikolinguistik. Bandung: Universitas Pendidikan Bandung Press.

Jesa, M. (2008). Efficient English Teaching: Methods, Lesson Format, Evaluation. New Delhi: APH Publishing Corporation.

Krashen, S.D. (1985). The input hypothesis: Issues and implications. London: Longman.

Lightbown, Pats, M. and Nina, S. (2006). How Languages Are Learned. Oxford: Oxford University Press.

Long, M. H. (1997). Construct Validity in SLA Research: A Response to Firth and Wagner. The Modern Language Journal, 81(3), 318-323.

Macaro, E. Continuum Companion to Second Language Acquisition. London: Continuum.

Maftoon, P., \& Shakouri, N. (2012). P.sycholinguistic Approach to Second Language Acquisition. The International Journal of Language Learning and Applied Linguistics World (IJLLALW. Vol 1 (1); 1-9 ISSN: 5389-2100

Matlin, M.M. (1994). Cognition. New York: Ted Buchholz.

Ramadhan, M. A. (2013). Applied Psycholinguistic: Review of EFL Teaching Methods in Building Up the Learners' Motivation. Makassar: Universitas Negeri Makassar.

Sanz, C. (2005). Mind and Context in Adult Second Language Acquisition: Methods, Theory, and Practice. Washington DC: Georgetown University Press. 